Retraction

\title{
Retracted: Clinical Brain Death with False Positive Radionuclide Cerebral Perfusion Scans
}

\section{Case Reports in Critical Care}

Received 9 March 2016; Accepted 9 March 2016

Copyright (C) 2016 Case Reports in Critical Care. This is an open access article distributed under the Creative Commons Attribution License, which permits unrestricted use, distribution, and reproduction in any medium, provided the original work is properly cited.

The article titled "Clinical Brain Death with False Positive Radionuclide Cerebral Perfusion Scans" [1] has been retracted as the scans in Case 2 of the article were interpreted incorrectly. As a result, the conclusions are not reliable.

\section{References}

[1] S. Venkatram, S. Bughio, and G. Diaz-Fuentes, "Clinical brain death with false positive radionuclide cerebral perfusion scans," Case Reports in Critical Care, vol. 2015, Article ID 630430, 5 pages, 2015. 